\title{
所謂「馬乘り」遊戯中に起つた下腿骨折に就て
}

\author{
On the Fracture of Leg in "Umanori" Playing.
}

日本醫科大學整形外科學敉室（主任 碓藤一男教授）

中西修

\section{Nakanishi Osamu.}

年と共にスポーッの盆々隆盛となるのは，吾人の喜 ぶべき事であるが，其反面にスボーッ外傷の次第に多

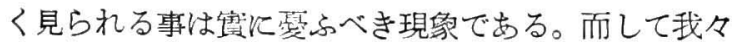
整形外科篦は之等所謂スポーッ外賃を研究し, 以てス ポーシに對する適宜の注意，隩正な指導をする事が肝 姴である。

私は最近馬乘り遊戯に於いて惹起せられた下眼骨折 5 例飞遭遇し, 聊知見を得たので敢て此處に趃告する 次第である。

\section{症例 1}

(患者)

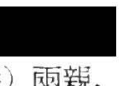
8 歲11ヶ月, 男

(家族憷) 兩親, 同胞 2 名, 侧れも健在, 遣傅的疾患 と思われるものを認め難い。

(既往症) 生來健康にして著息を識らないとの事であ る。

(現病歷) 昭和 27 年 9 月 1 日朝反達 12 人が 6 人宛 2 組に分れ, 患者達の組が馬となり馬乘り遊戯をし た。㭧者は最後尾の馬となり, 頭を前者の馬の股の中 に入れ, 兩上䏠にて前者の馬の大腿部を抱く棁にして

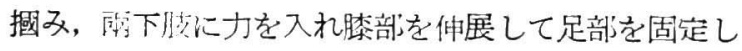
ていた。㭧者の肩闲に 1 人乘り, 次の者が左後方より
力一杯走り來り患者の腰部に飛び乘つた。其瞬間患者 は兩滕を伸ばして足に力を入れて之を支えたが支えき れず轉倒した。その時の肢位は, 兩上肢は前者の馬の 大腿部をはなす事なく, 右膝部は屈曲し腓側踝を下に,

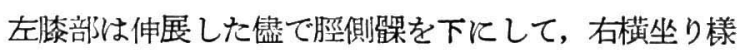
に 2 人を乘せた焦倒れた。乘者 2 人が降りたので立ち 上らうとしたが左下腿上部に激痛があり立ち上る事が 出來なかつた。

（現症）體格, 榮䕉共に中等度, 靑色翠膜は認めず, 胸腹部其他の部位に異常を認めない。䒚血液檢査にも 異常を認めない。

（局所々見）左下腿上部郎ち左膝關節より約 $4 \mathrm{~cm}$ 下 部は稍腫脹し, 輕度の局所熱感艾び發赤を認め, 自發 痛あると共に型痛著明にして軋軑昔を認めた。左下眼 に著明な變形は認め難いが自動的運動は不能である。

(X線所見) 正面像に於いては, 脛骨上端より約 $4 \mathrm{~cm}$ 下部に脛側より腓側に走る横骨折線があり, 此骨折線 と同高に腓骨にも横骨折線めり, 而も脛骨の脛側より 約 $1 /:$ 內方の部分より斜上方に向い骨端線に及ぶ骨折 線あり, 從つて脛骨々幹端部の腓側部汇三角形を呈し た骨折破片を認める。側面像に於いては, 腓骨の骨頭 の高さに於いて脛骨後方より斜前下方郎 ち脛骨結節部浮向ふ骨折線むり, 而子脛

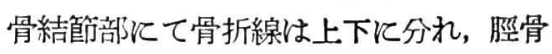
結篰は三伍形の骨折破片となるのが認め られる。腓骨にも骨頭より約 $3 \mathrm{~cm}$ 下部 飞橫骨折線を認める。

(治療並に經過) 昭和 27 年 9 月 1 日入 院冷濕布, 副木固定を施し腫脹の輕減を 待つて, 9 月 6 日ギブス繃帶を施し 9 月 8 日退院した。10月 3 日よりギブスを切 り開きマッサージを行い, 10月下旬全く 機能障码を貽寸事なく治癒した。

症例 2

(息者) 
(家族歷並に既往歷) 共に特記すべき事項を認めな w。

(現病歴) 昭和 27 年 10 月 27 日畵休2時馬乘り遊

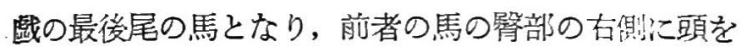

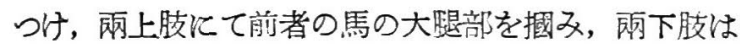
滕部を屈曲していた。肩部に 1 人乘り次の者が腰部に

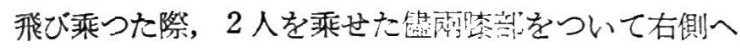
坐る樣囀倒した。立ち上つたが右下肢に疼痛があり 又倒れた。

（來院時所見）能格，策養共:中等度，胸腹部其他の 部位，血液諸险查飞暴常を認めない。局所々見は右足 關節部より約 $6 \mathrm{~cm}$ 上部は稍腫脹し, 輕度の局所熱感

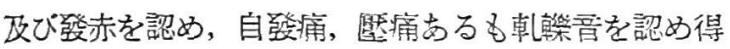
ない。右下眼に著明な變形は証め難く自動的運動は不 能でする。

(X線所見) 正面像心於いては，胈骨の中 $1 / 3$ と下 $1 / \%$ の境界部の腓測より，並に脛骨下 $1 / 3$ の略中央部脛骨 下端骨端線儿向、斜下方摆旅狀に走る 2 骨新線を認

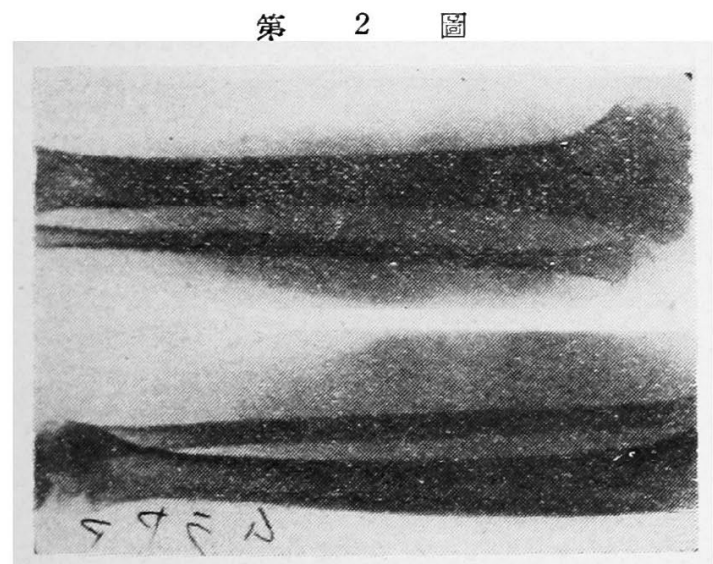

める。側面像に於いては，脛骨の中 $1 / 3$ と下 $1 / 3$ 境界 部の後方上より斜下方脛骨の下 $1 / 3$ の略中央部に走

る, 螺旋狀の 1 骨折線を認めた。

(治㙩並に經過) 昭和 27 年 10 月 27 日副木固定し 1 週間後ギブスシーネで固定, 11 月 20 日よりマ\% サージ, 12 月上旬全く機能障碍を貽す事なく治癒し た。

\section{症例 3}

（患者）志賀某, 15 歲 6 ケ月, 男

(家族歷並々既往歷)特記事項を認めず。

(現病歷) 昭和 27 年 10 月 29 日症例 2 の場合と同 樣に, 患者は馬乘り遊戲の最後尾の馬となり, 頭は前 者の馬の留部の右側におき, 兩上肢にて前者馬の大眼 部を持つて下肢は輕く屈曲し, 肩, 腰部に 2 人乘せて いた。更にす51 人が飛び乘つた時右側へ坐る樣に轉
倒した。左下肢に疼痛な覺え起士不能となり來院し た，佮轉倒した際に左下肢に音を感じたとの事であ る。

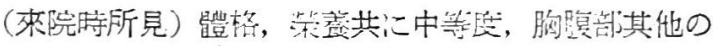

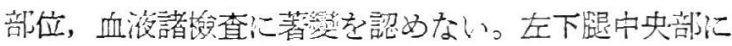
輕度の腫脹, 虹赤, 熱感あり, 自登痛, 壓痛出り, 變 爷は認め得ないが自動的運動は下能である。

\section{第 3 圖}

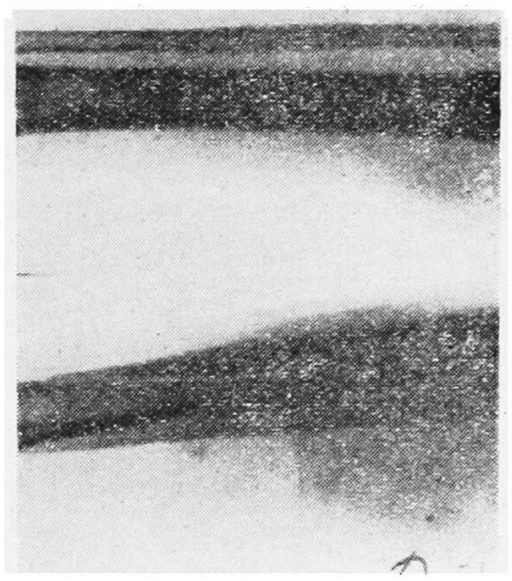

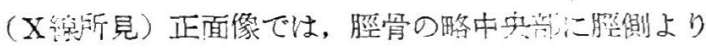
罪側に向つて斜下方に走る骨折腺の存するを認める。

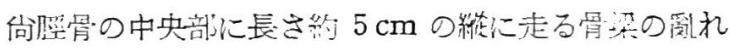
ている部分の存するのを認める。側面像では, 脛骨の 中央部得方の約 $1.5 \mathrm{~cm}$ 踓れた 2 ケ所より前下方に走 る2骨折線㟧り。而も此2 肙折線は脛骨の略中央で垂 なり，前下方脛骨の下端より $3 \mathrm{~cm}$ 上左に走るのが認 められる，而も此骨折線の少し離開しているのが認め られる。

(治療並に經過) 昭和 27 年 10 月 29 日副木国宣， 3 週後よりマッサージ，12月上旬至く科㴰陪碍な䀫 す尋なく治檷した。

症例 4

(患者) 大町某, 12 歲, 男

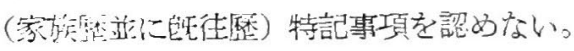

(現病㰮) 昭和 27 年 11 月 16 日馬乘り遊尷の最後 尾の馬となり，頭を前者の馬の简部の右偩につつ怰雨上

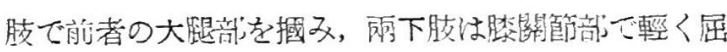
曲し，肩部に1人乘せていた。呮の者が飛び乘つた時 筑势がくずれ轉倒しさうになつた。其橓間非の者が飛 び乘つた篇 3 人を乘せた睢坐るよ5に右側に轉倒乙 え，轉倒の際下腈に音がし同時に左下腿に激挃を感じ 
た。

(來院时所見) 左下腿下 $1 /$; の部に腫脹, 發赤, 熱感

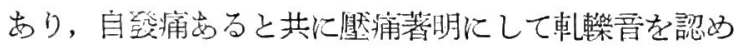
た。左下腿に著明な綂无を認め難いが，自動的運動は 全く下能でる。其他身體各部には著變を認めなかつ た。

第 4 圆
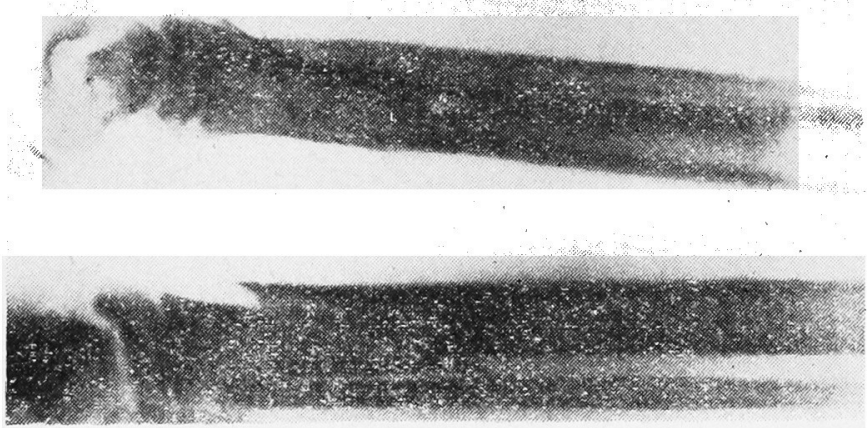

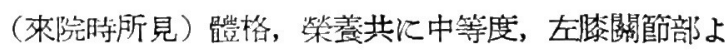
り約 $4 \mathrm{~cm}$ 部は稍腫脹し, 發赤, 熱感岕り, 輕度の自 登痛あると共櫭痛は著明であるが，軋軪音，下腿の 著明な變形は認め難く，自動的運動は不能である。

(X線所見) 正面像泛於いては, 脛骨上端より約 $4 \mathrm{~cm}$ 部㳻骨折線を認めるが腓骨には骨折を認めない。側 面像に於いては脛骨上端より約 $4 \mathrm{~cm}$ 下部に 横骨折線があり，而もとの骨折線は䐉骨結節 の略中央部に存するのが認められる。腓骨に

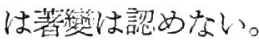

(治憭並に經逼) 昭和 27 年 12 月 3 日副木 固定，12月 10 日ギブス繃帶を施し，1月上 旬ギブスを切り開きマッサージを行い，1月 下旬䇝能障碍を貽す事なく治癒した。

\section{考按}

スポーシによる下腿骨折は轉倒, 衝突, 跳 躍, 我躍, 捻轉等の椮轉により惹起せられる

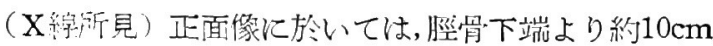
の腓側より斜下方䐅側踝約 $3 \mathrm{~cm}$ 上部飞改ぶ螺旋狀の 2 骨折線があるのを認める。台脛骨腓側飞も腓側を底 邊とした三角形の他の骨折片を認める。腓側飞も下端 より約 $4 \mathrm{~cm}$ 亿斷端不正の骨折線を認める。膯骨, 腓 骨の骨折線より下端は共に腓側に轉位するのを認め る。㑡面渗では下端上り約 $10 \mathrm{~cm}$ 上方の前方より㷋 方に走る骨折線があり，兩骨折線間比 2 箇の三角形老 呈する骨片の存するのを認める。腓骨とも下端より約 $4 \mathrm{~cm}$ の部に橫骨折線を認める。

(治撩並に紅過) 昭和 27 年 11 月 16 日入院, 冷濕 布, 副大固完を施し，11月 24 日喢脹輕減したのでギ ブス繃帶を施し，11月 27 日退院，12月15 日ギブス を切り開きマッサージを行い，1月上旬殆ど 機能障碍索貽す事なく治瘑した。

\section{症 例 5}

（患者）小模，13歲４ヶ月，男

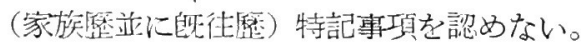
(現症) 昭和 27 年 12 月 3 日馬乘り遊歔の 最後尾の馬となり, 前者馬の股の洷をい れ，雨上法にて前者馬の大腿部を抱く㥞にし

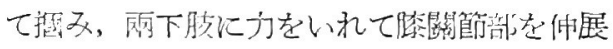
てていた。费者の肩部に 1 人乘り，炏の者が 㷋方より走り茳り勢よく患者の上に飛で乘つ

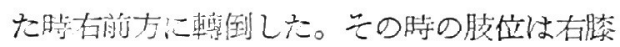

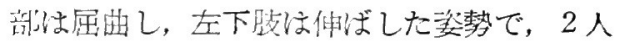

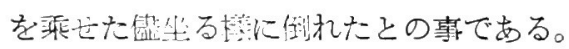

\section{ものが多い。}

私は馬乘り遊戯中に惹起せられた下腿骨々折の 5 例 を經㯺した。而もとの中の 2 例, 郎ち症例 1 は䐉骨並 に腓骨々折であり, 症例 5 は鳃骨のみの骨折であるが, 新述の如く現症並にその骨折部位は略類似している。 而もこのよ5な骨折は比較的稀で，その登生機轉は兩 症例共に, 兩槂關節部を伸展して兩足部々力を入れて 足部を固定し乘者を支克ていた際，他の乘者が急汇飛 び乘つた爲支持する事が不能となり轉倒したもので ある。然し頭部を前者の馬の股の中に入れて固定して いたために签易に前方に轉倒することが出來ず，その

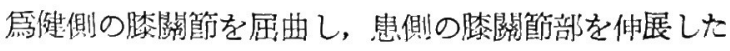
㒒健側の斜め前方に横に轉倒したものと考兄られる。

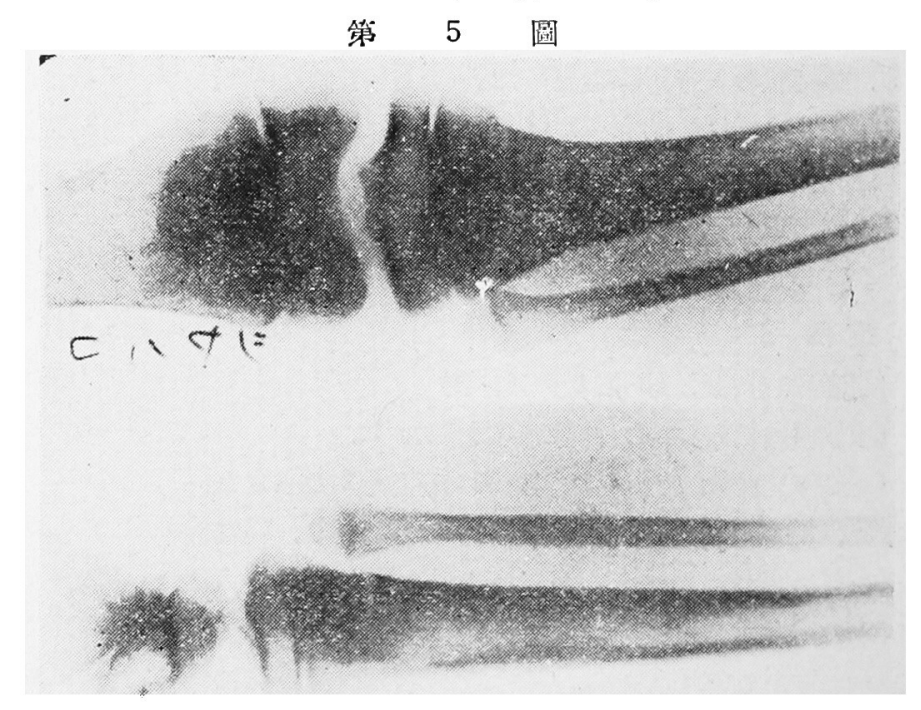


郎ち滕關節部を伸展している祭には特に大眼四頭筋, 下眼三頭筋が作用しているが，伸展した睢內則則方へ

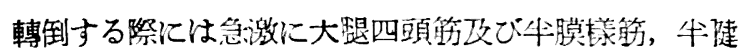

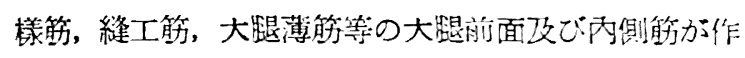
用する結果, 膝關節部の支持作用の平衙狀態變化を 起し, 之等の大眼骨前面及び內側の筋肉の緊桭によつ

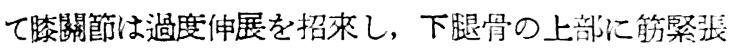
による過度伸展を生し，其絬果骨折を惹起したものと 考吕れる。

次症例 2 , 症例 3 , 症例 4 江筐生機轉を同じく し，野球の投球或は槍投げ又腕相撗の㳟合に見られる

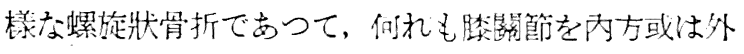
方へ捻轉卞る結果惹起した螺旋狀骨折で, 足部を固定 せる結果生ずるものと考兄られる。

以上の如く私は最近馬乘り遊戲中心惹起した下跟骨。 折 5 例を續いて經駼したので敢て報告すると共に，ス ポーッ障碍化對する大方の注意を喚起する头第であ る。

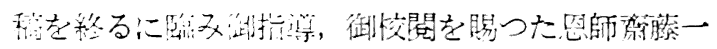

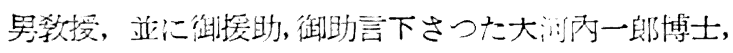

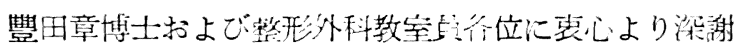
する。

\section{第 42 回 基礎医学談話會}
日 時：昭和 28 年 3 月 18 日(水)
場 所：第二請 堂

\section{鉄吸収に及ぼす amino 酸の影䍌}

栄鳌学教宝松井文莫

島田敏夫

前報に於て各種天然 amino 敢の腸管からの吸收 に種々の効果を斎らすことを識つたのて，その效果を 示す機作を窥ひ知らうとして次の実娩を行つた。

1) 非天然 amino 酸の影響

2） $\boldsymbol{\alpha}$-amino 酸の $\boldsymbol{\alpha}$ 位の amino 基が $\mathrm{H}, \mathrm{O}$ ，て金 換した物質の影響

3） $\alpha$-amino 酸の amino 基を benzoyl 基员 formyl 基で置換し amino 基の作用をblockした物質 の影斐

4) 一二の amino 醉の構成分子個々:就ての寒騾

5） carboxyl 基を amid の型にしたもの及一絽
午后 4 時 30 分 $\sim 6$ 琤

当番: 栄荃学教空

amineの影㗽に就ての䍜怙

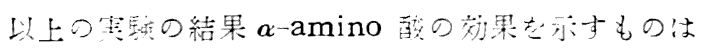
$\boldsymbol{\alpha}$-amino 基であり且 amino 基が游離であることが 必要でるるcarboxyl 基も间标の状態でることが 条件らしい。更に amino 酸の個々の分子の紛果から は本来の醋の効率を推定出来ない事等が結目された。

本邦人上肢動脈管についての一二計

測とその組織学的構造

解部教室今护地一

上敗動眽 31 ケ所について臣径を計测し、へマトキ シリン・エオジン染色站さ゚にワイゲルト弾性絲維染色

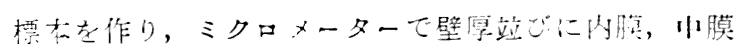

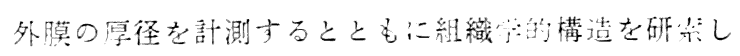
た。詳しくは原著 3 月号揭㬸を参照せられ度し。 